University of Nebraska - Lincoln

DigitalCommons@University of Nebraska - Lincoln

1995

Estimating Predatory Efficiency of Episyrphus balteatus (Diptera: Syrphidae) in Cereal Fields

\author{
Brigitte Tenhumberg \\ University of Nebraska - Lincoln, btenhumberg2@unl.edu
}

Follow this and additional works at: https://digitalcommons.unl.edu/bioscifacpub

Part of the Life Sciences Commons

Tenhumberg, Brigitte, "Estimating Predatory Efficiency of Episyrphus balteatus (Diptera: Syrphidae) in Cereal Fields" (1995). Faculty Publications in the Biological Sciences. 209.

https://digitalcommons.unl.edu/bioscifacpub/209

This Article is brought to you for free and open access by the Papers in the Biological Sciences at DigitalCommons@University of Nebraska - Lincoln. It has been accepted for inclusion in Faculty Publications in the Biological Sciences by an authorized administrator of DigitalCommons@University of Nebraska - Lincoln. 


\title{
Estimating Predatory Efficiency of Episyrphus balteatus (Diptera: Syrphidae) in Cereal Fields
}

\author{
BRIGITTE TENHUMBERG \\ Department of Biological Sciences, Simon Fraser University, Burnaby, BC V5A 1S6 Canada
}

\begin{abstract}
Environ. Entomol. 24(3): 687-691 (1995)
ABSTRACT A model was developed to estimate the effect of predation by Episyrphus balteatus larvae on aphid populations in fields of winter wheat. Feeding rate of syrphid larvae was estimated from experiments in field cages using a Holling type-III function. During larval development, syrphids consumed a maximum of 396 aphids, which is only half the potential feeding rate reported from laboratory experiments. The lower consumption rate in the field may be attributed to the additional time required by the predators to find prey. Isoclines derived from the model were used to estimate the abundance of syrphid larvae necessary to prevent further pest increases.
\end{abstract}

KEY WORDS syrphids, model, consumption rate

APHIDOPHAGOUS SYRPHID LARVAE are important predators of cereal aphids (Storck-Weyhermüller 1988, Groeger 1992, Tenhumberg \& Poehling 1995). In northern Germany the most abundant syrphid species is Episyrphus balteatus (De Geer), constituing $>90 \%$ of all syrphids in the field (Tenhumberg \& Poehling 1991, Tenhumberg 1992). After migration into cereal fields, syrphid females lay their eggs in response to aphid density. If syrphid larvae hatch early in the buildup of aphid populations, they are often able to prevent aphid outbreaks, especially in southern Germany (Tenhumberg \& Poehling 1995).

Considerable research has been carried out on the voracity of this species in the laboratory (Table 1 ), because of the importance of $E$. balteatus in limiting aphid abundance. The results have been extremely variable. For example, the estimated maximum number of aphids consumed by $E$. balteatus during larval development varies between 140 and 1,322 third-instar or medium-sized aphids, depending on temperature and aphid species (Wahbi 1967, Ankersmit el al. 1986, Tenhumberg 1992). Even at the same temperature, the laboratory voracity may vary by up to $600 \%\left(17^{\circ} \mathrm{C}\right.$ [Table $1]$ ); this variation can only be partly explained by differences in aphid size or nutritional value. For example, in the experiments of Ankersmit et al. (1986), aphids were presented on leaves, whereas Tenhumberg (1992) presented aphids without leaves. The resulting different searching areas of syrphid larvae might be responsible for the variation in voracity recorded by those authors. Furthermore, mortality in the experiments of Ankersmit et al. (1986) was more than twice that observed in Whabi's (1967) and Tenhumberg's (1992) experiments (70\% versus $15-30 \%$, respectively), indi- cating that the syrphid larvae used by Ankersmit et al. (1986) were exposed to higher stress.

The laboratory voracities reported in Table 1 cannot be applied directly to natural conditions. The syrphids were usually reared in small arenas such as petri dishes. The voracity estimated under such conditions is determined mainly by satiation; it does not take into account the time needed to locate prey. Although aphid consumption in the field is probably lower than indicated by laboratory estimates (Luck et al. 1988), it is common to use such data to estimate the influence of syrphid larvae on the population dynamics of aphids (Chambers \& Adams 1986, Hagley \& Allen 1990).

In the study reported here, the effect of syrphid larvae was estimated in field cages that were approximately the same size as the foraging area of larvae in the field (unpublished data). From these data, a model was constructed to predict the potential of syrphid larvae in controlling aphid populations.

\section{Materials and Methods}

The experiments were conducted in 10- $\mathrm{m}^{2}$ cages placed in fields of winter wheat during the summers of 1989-1991. These cages were divided into two parts with gauze. At the beginning of June, cereal plants (EC 49) inside the cages were infested with two aphid species, Sitobion avenae (F.) and Metopolophium dirhodum (Walker). Four-d-old syrphid larvae were released when aphid densities were between 5 and 10 aphids per shoot. In some cases, higher densities were reached because the sampling schedule missed the beginning of exponential aphid growth. Sufficient syrphid larvae were released to establish initial predator-prey ra- 
Table 1. Number of aphids consumed during larval development and mortality of $E$. balteatus larvae at different temperatures

\begin{tabular}{|c|c|c|c|c|c|}
\hline Aphid species & $\begin{array}{l}\text { Instar or size } \\
\text { of aphids }\end{array}$ & Temp, ${ }^{\circ} \mathrm{C}$ & $\begin{array}{l}\text { Mortality } \\
\text { of syrphid } \\
\text { larvae, \% }\end{array}$ & No. of aphids & Source of data \\
\hline S. avenae (F.) & Third instar & 17 & 70 & 140 & Ankersmit et al. (1986) \\
\hline \multirow[t]{4}{*}{ M. dirhodum (Walker) } & Third instar & 14 & 20 & 1,113 & Tenhumberg (1992) \\
\hline & & 17 & 15 & 1,041 & Tenhumberg (1992) \\
\hline & & 20 & 23 & 886 & Tenhumberg (1992) \\
\hline & & 22 & 27 & 658 & Tenhumberg (1992) \\
\hline \multirow[t]{3}{*}{ Aphis fabae (Scopoli) } & Medium size & 15 & 30 & 553 & Wahbi (1967) \\
\hline & & 20 & 30 & 407 & Wahbi (1967) \\
\hline & & 25 & 27 & 1,322 & Wahbi (1967) \\
\hline
\end{tabular}

tios between 1:40 and 1:245 (Table 2); these predator-prey ratios are frequently found in cereal fields (Tenhumberg 1992). In one cage half, no predators were released, to examine aphid development in the absence of syrphid larvae (=control). Aphid density was calculated by counting all aphids on 50 randomly selected plants per plot at three times: just before and at 3 and $6 \mathrm{~d}$ after the release of syrphid larvae. The syrphid consumption rate was estimated by comparing growth rates of aphid populations, $r_{N}$, in cages in the presence and absence of syrphid larvae. $r_{N}$ was estimated using the following formula of Entwistle \& Dixon (1987) was used:

$$
r_{N}=\frac{\ln \left(D_{t_{2}}+0.01\right)-\ln \left(D_{t_{1}}+0.01\right)}{t_{2}-t_{1}}
$$

where $D_{\mathrm{t} 1}$ and $D_{\mathrm{t} 2}$ are the aphid densities at time $t_{1}$ and time $t_{2}$, respectively.

Equation 1 assumes that aphid populations grow logarithmically and therefore should only be used for calculations over short periods. $r_{N}$ was computed for each counting interval $(3 \mathrm{~d})$. Under the assumption that aphid populations in each cage half increase at the same rate, the reduction of $r_{N}$ $(R)$ caused by predators can be estimated by substracting $r_{N}$ of the control cage $\left(\mathrm{Cr}_{N}\right)$ from $r_{N}$ in the cages with predators $\left(\mathrm{Sr}_{N}\right)$ :

$$
R=\mathrm{C} r_{N}-\mathrm{S} r_{N}
$$

Table 2. Experimental design used to establish different predator-prey ratios in field cages

\begin{tabular}{ccccl}
\hline \hline Date of release & EC $^{a}$ & $\begin{array}{c}\text { No. aphids } \\
\text { per shoot }\end{array}$ & $\begin{array}{c}\text { No. } \\
\text { released } \\
\text { larvae }\end{array}$ & $\begin{array}{l}\text { Pred- } \\
\text { ator- } \\
\text { prey } \\
\text { ratio }\end{array}$ \\
\hline 24 June 1989 & 69 & $22.0 \pm 6.3$ & 1,060 & $1: 70$ \\
27 June 1989 & 69 & $22.0 \pm 7.0$ & 460 & $1: 170$ \\
3 July 1989 & 71 & $55.5 \pm 7.7$ & 642 & $1: 245$ \\
11 June 1990 & 49 & $8.1 \pm 3.7$ & 300 & $1: 110$ \\
3 July 1991 & 50 & $24.2 \pm 7.5$ & 960 & $1: 70$ \\
8 July 1991 & 55 & $6.8 \pm 2.5$ & 280 & $1: 70$ \\
8 July 1991 & 55 & $5.2 \pm 1.9$ & 85 & $1: 170$ \\
10 July 1991 & 57 & $5.0 \pm 2.0$ & 120 & $1: 120$ \\
10 July 1991 & 57 & $6.6 \pm 2.7$ & 110 & $1: 170$ \\
12 July 1991 & 57 & $7.7 \pm 2.9$ & 330 & $1: 40$ \\
\hline
\end{tabular}

${ }^{a}$ Growth stage of Zadoks et al. (1974).
The correlation between $R$ and the predatorprey ratios was tested by calculating the Pearson correlation coefficient (Sokal \& Rohlf, 1981).

\section{Results}

The effect of syrphid larvae on aphid populations at different initial predator-prey ratios is shown in Fig. 1. Although syrphid larvae tended to reduce $r_{N}$ more at higher predator-prey ratios (i.e., higher number of aphids per syrphid larva), these variables were not significantly correlated (Pearson correlation coefficient $=0.239, p=0.507$ ). Thus, no reliable predictions of syrphid voracity based on actual predator-prey ratios could be made.

Instead, syrphid voracity was estimated as follows. The increase of an exponentially growing aphid population per time interval, $d N / d t$, is given by the product of the population growth rate $r_{N}$ and the number of individuals $N$ at time $t$ :

$$
\frac{d N}{d t}=N r_{N}
$$

Integrating equation 3 with respect to time $t$ we obtain:

$$
N=N_{0} e^{t r_{N}} .
$$

In equation $4, r_{N}$ denotes the growth rate of the aphid population in the absence of predators (con-

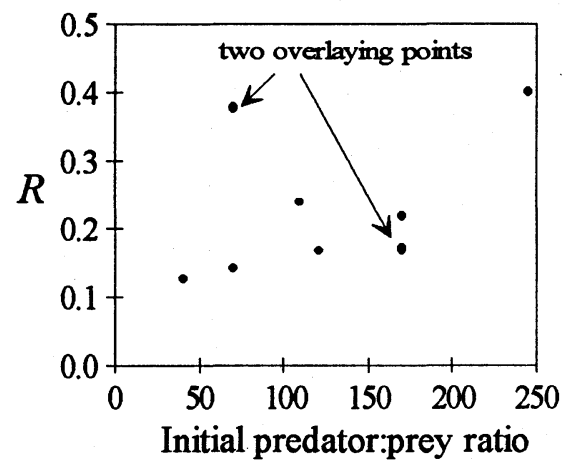

Fig. 1. Relationship between initial predator-prey ratio and the resulting reduction of the growth rate of aphids, $R$ (for calculation of $R$ see Materials and Methods). 


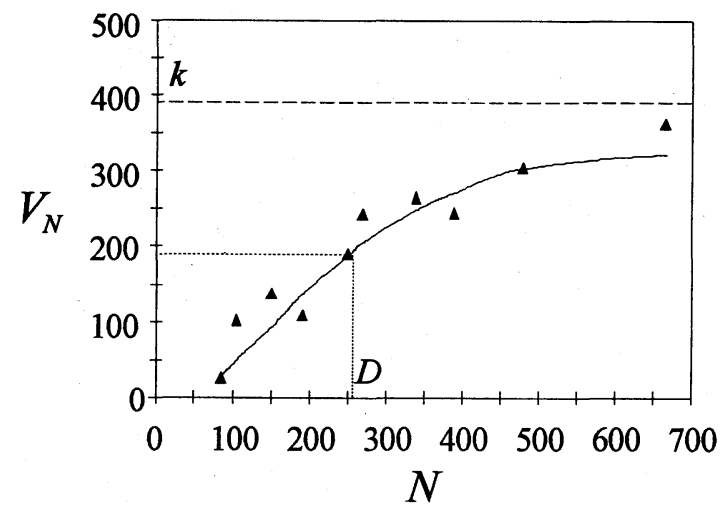

Fig. 2. Voracity $\left(V_{N}\right)$ of syrphid larvae as a function of aphid abundance $(N)$.

trol), $N_{0}$ the aphid numbers in the presence of predators at the beginning of the time interval $t$ (in days), and $N$ is the number of prey available for syrphid larvae. The difference between $N$ and the actual aphid density at time $t\left(N_{t}\right)$ divided by the number of syrphid larvae released $(P)$ is an estimate of actual syrphid voracity $\left(V_{N}\right)$ :

$$
V_{N}=\frac{N_{0} e^{3 r_{N}}-N_{3}}{P}
$$

The voracity $V_{N}$ was a nonlinear function of $N$. The distribution of cereal aphid populations is clumped, especially at low density. With increasing density, aphid populations get closer to a random distribution (Ohnesorge \& Viereck 1983). Therefore, I assumed that the voracity of syrphid larvae accelerated at low aphid density and decelerated at higher densities because of a maximum rate of consumption. This is best described by the Holling type-III function (Holling 1966):

$$
V_{N}=\frac{k N^{2}}{N^{2}+D^{2}}
$$

where the parameter $D$ specifies the amount of prey consumed when half of the maximum feeding rate $k$ is reached. From a nonlinear regression analysis of the estimated voracity on the number of aphids available, I obtained $k=396$ and $D=$ 256 ( $r=0.9 ; p \leq 0.001$ [Fig. 2]).

In addition the influence of syrphid voracity on the increase of aphid populations was estimated. If there is no interference between syrphid larvae, the development of the aphid population can be described as follows (Wissel 1989):

$$
d N / d t=N r_{N}-P V_{N}
$$

The growth of the aphid population $d N / d t$ will be zero if the net rate of increase $\left(N r_{N}\right)$ is equal to the prey consumption rate by syrphid larvae $\left(P V_{N}\right)$ that is, if

$$
N r_{N}=P V_{N}
$$

Replacing $V_{N}$ of equation 8 with the Holling type-

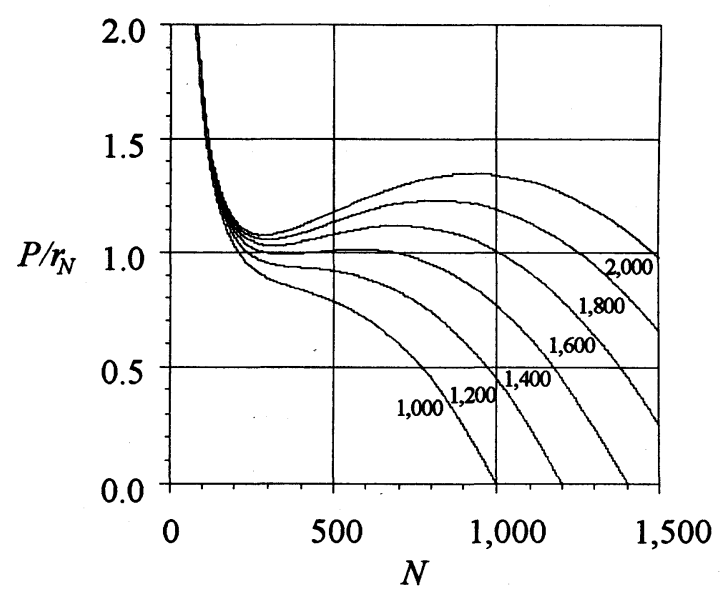

Fig. 3. $N$ isoclines for different $z$ values $(N, P=$ density of aphids, predators; $z=$ maximum density of aphid population; $r_{N}=$ growth rate of aphid population).

III function and expressing the rate of increase of aphid populations $\left(N r_{N}\right)$ with the logistic Verhulstfunction (Verhulst 1883) we obtain:

$$
N r\left(1-\frac{N}{z}\right)=P \frac{k N^{2}}{N^{2}+D^{2}}
$$

The Verhulst-function takes into account that population growth declines as aphid density approaches the maximum value of $z$. As noted above, the values of $k$ and $D$ are 396 and 256. Suppose further that the value of $z$ is between 1,000 and 2,000. Thus, zero-growth isoclines can be drawn (Fig. 3). Each isocline illustrates all quotients $P / r_{N}$ for a given $z$ value where the amount of prey consumed is equal to the net reproduction of the pest (stable system). Extreme values of $P / r_{N}$ (minimum, maximum, inflexion point) only exist for $N \geq 200$. For $N<200$, the curves join into a monotonically decreasing function. This means that, in the case of low-aphid densities, the number of predators necessary to reduce the pest density under some threshold will be independent of the maximum value of $N$. With regard to pest management (economic injury threshold), an aphid abundance of 510 individuals per shoot is tolerable (Wetzel \& Schütte 1988, Basedow et al. 1989, Mann et al. 1986). In this range of low aphid numbers, $z$ can be ignored and $P$ can be expressed as a function of $N$ :

$$
P=\frac{r_{N}\left(N^{2}+D^{2}\right)}{k N} .
$$

Thus, zero growth isoclines can be derived directly from equation 10 (Fig. 4).

\section{Discussion}

In this study, the effect of $E$. balteatus larvae on aphid populations was estimated in field cages that provided foraging conditions similar to those in the 


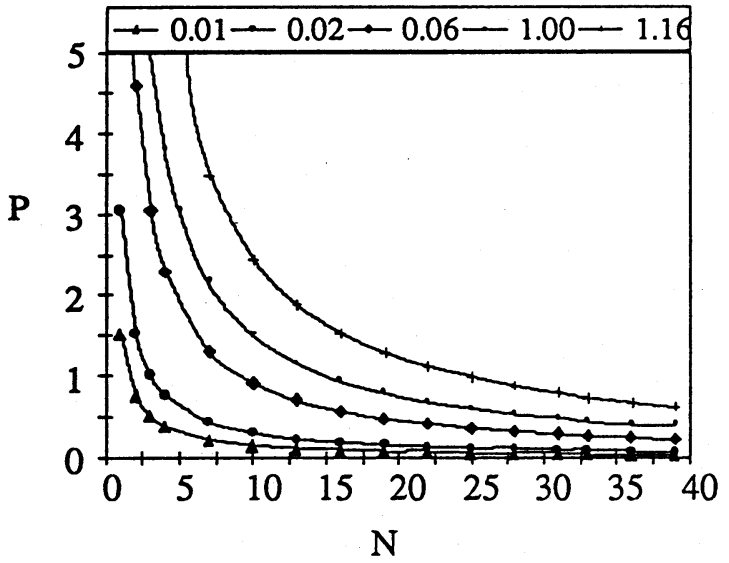

Fig. 4. $\mathrm{N}$ isoclines for different growth rates of aphid population $\mathrm{r}_{N}(N, P=$ density of aphids, predators).

field. Estimation was based on the Holling typeIII function; thus, both satiation of the predators as well as the time for handling and for locating the prey were taken into account. In contrast to the Holling type-II function, the logistic shape of the Holling type-III function also reflects the accelerating voracity of syrphid larvae at low aphid density as a result of the clumped distribution of aphids.

The feeding rate of syrphid larvae was calculated for the first $6 \mathrm{~d}$ after release of 4-d-old larvae. During the first $4 \mathrm{~d}$ and the last 1 or $2 \mathrm{~d}$ of larval development, the food demand of the predators is negligible (Tenhumberg 1992). The first larvae pupated $7 \mathrm{~d}$ after release. Thus, their prey intake was concentrated in the observation period of 6 days. Therefore, a single predator consumed a maximum of 396 aphids during its larval development, which is only half of the mean potential voracity given in the literature. Thus, estimating predatory efficiency of syrphid larvae on the basis of their potential voracity may lead to an overestimation of their actual impact on the pest in the field.

Apart from the maximum feeding rate, the flat shape of the Holling type-III function in Fig. 2 suggests that the adaptation of the predators' consumption rate to varying food supplies holds for a relatively wide range of aphid abundance. This is important for controlling pest populations because it indicates that syrphid larvae will respond immediately to changing aphid abundance (e.g., to increasing aphid reproduction as a result of improved environmental conditions).

However, the predation efficiency of syrphid larvae is highly dependent on the growth rate of pest populations. As shown in Fig. 1, a given predatorprey ratio representing the predation pressure at a certain time is unsuitable to predict the decrease of the aphid population. To estimate syrphid impact, the ratio between the net increase of aphid populations and the number of aphids consumed per time interval has to be taken into account
(Bombosch 1963). My study utilized a general predator-prey model where the development of aphid populations was described by the Verhulstfunction and syrphid voracity by the Holling typeIII function. With this model the numbers of syrphid larvae necessary to prevent a further increase of aphid populations at different aphid densities and growth rates could be determined. Two rules for stability in this system could be derived from the isoclines: (1) Syrphid density required to prevent a further increase of aphid abundance rises with improved developmental conditions for the pest and the resulting increase of their growth rate; (2) The predation efficiency decreases with decreasing aphid infestation as a result of increased search time. At higher aphid abundances, the predators are able to adapt their feeding rate to the actual supply of resources. Therefore, the density of syrphid larvae needed to prevent net population growth of the pest remains at a low level.

This model has been developed assuming lowaphid abundances. It is likely that at high-pest abundances the density of predators needed to produce stability will increase. As the pest population approaches its maximum value $(z)$, the rate of population growth decreases and the syrphid density required to produce stability will decrease.

If a pest growth rate of 1.16, as recorded in the control cage, is taken as a basis, then the predator density required to keep the pest below 10 individuals per shoot (economic injury level) is 2.4 larvae. However, the natural abundance of syrphid larvae is normally $<0.4$ individuals per shoot (Adams 1984, Groeger 1992, Tenhumberg 1992). In the field, interactions with other restricting factors will lead to a lower pest growth rate. During field research conducted simultaneously in winter wheat, mean $r_{N}$ values that were an order of magnitude lower than recorded in the field cages (0.03-0.015) were observed before immigration of syrphid females in areas without insecticide application (Tenhumberg 1992). Using $r_{N}=0.02,0.3$ syrphid larvae per shoot are necessary to prevent an increase of aphid populations to $>10$ individuals per shoot. Although syrphid larvae frequently reach the required abundance in the field, the model needs to be validated under natural conditions.

\section{Acknowledgments}

I thank Manfred Mackauer, Bernard D. Roitberg, Andrew J. Tyre, and anonymous reviewers for their valuable comments on an early draft of the manuscript. This research was supported by the German Research Foundation Project No. IIB8-Te 196/2-1.

\section{References Cited}

Adams, T.H.L. 1984. The effectiveness of aphid-specific predators in preventing outbreaks of cereal aphids. Ph.D. dissertation, University of East Anglia, Norwich, UK. 
Ankersmit, G. W., H. Dijkman, N. J. Keuning, H. Mertens, A. Sins \& H. M. Tacoma. 1986. Episyrphus balteatus as a predator of the aphid Sitobion avenae on winter wheat. Entomol. Exp. Appl. 42: 271277.

Basedow, T., C. Bauers \& G. Lauenstein. 1989. Ergebnisse vierjähriger Untersuchungen zur gezielten Bekämpfung der Getreideblattläuse (Homoptera, Aphididae) im intensiven Winterweizenanbau: Optimaler Termin und Bekämpfungsschwellen. Mitt. Biol. Bundesanst. Land. Forstwirtsch. Berl. Dahlem 254: $1-63$.

Bombosch, S. 1963. Untersuchungen zur Vermehrung von Aphis fabae Scop. in Samenrübenbeständen unter besonderer Berücksichtigung der Schwebfliegen (Diptera, Syrphidae). Z. Angew. Entomol. 52: 105141.

Chambers, R. J. \& T.H.L. Adams. 1986. Quantification of the impact of hoverflies (Diptera: Syrphidae) on cereal aphids in winter wheat: an analysis of field populations. J. Appl. Ecol. 23: 895-904.

Entwistle, J. C. \& A.F.G. Dixon. 1987. Short-term forecasting of wheat yield loss caused by the grain aphid (Sitobion avenae) in summer. Ann. Appl. Biol. 111: 489-508.

Groeger, U. 1992. Untersuchungen zur Regulation von Getreideblattlauspopulationen unter dem Einflu $\beta$ der Landschaftsstruktur. Agrarökologie 6: 1-169.

Hagley, E.A.C. \& W. R. Allen. 1990. The green apple aphid, Aphis pomi DeG. (Homoptera: Aphididae), as prey of polyphagous arthropod predators in Ontario. Can. Entomol. 122: 1221-1228.

Holling, C. S. 1966. The functional response of invertebrate predators to prey density. Mem. Entomol. Soc. Can. 48: 1-86.

Luck, R. F., B. M. Shepard \& P. E. Kenmore. 1988. Experimental methods for evaluating arthropod natural enemies. Annu. Rev. Entomol. 33: 367-391.

Mann, B. P., S. D. Wratten \& A. D. Watt. 1986. A computer-based advisory system for cereal aphid control. Comput. Electron. Agric. 1(3): 263-270.

Ohnesorge, B. \& A. Viereck. 1983. Zur BefallsdichteAbschätzung bei Getreideblattläusen. Z. Pflanzenkr. Pflanzenschutz 90(2): 213-219.
Sokal, R. R. \& F. J. Rohlf. 1981. Biometry: the principles and practice of statistics in biological research. Freeman, New York.

Storck-Weyhermüller, S. 1988. Einflu $\beta$ natürlicher Feinde auf die Populationsdynamik der Getreideblattläuse im Winterweizen Mittelhessens (Homoptera: Aphididae). Entomol. Gen. 13(3-4): 189-206.

Tenhumberg, B. 1992. Untersuchungen zur Populationsdynamik von Syrphiden in Winterweizenfeldern und Quantifizierung ihrer Bedeutung als Antagonisten von Getreideblattläusen. Ph.D dissertation, University of Göttingen.

Tenhumberg, B. \& H.-M. Poehling. 1991. Studies on the efficiency of syrphid larvae, as predators of aphids on winter wheat, pp. 281-288. In L. Polgar, R. J. Chambers, A.F.G. Dixon \& I. Hodek [eds.], Behaviour and impact of Aphidophaga. SPB Academic, Den Haag, Niederlande.

Tenhumberg, B. \& H.-M. Poehling. 1995. Syrphids as natural enemies in Germany: aspects of their biology and efficacy in different years and regions. AGEE 52: 39-43.

Verhulst, J. H. 1883. Notice sur la loi que population suit dans accroissement. Corr. Math. Phys. 10: 113121.

Wahbi, A. A. 1967. Untersuchungen über den $\operatorname{Einflu} \beta$ der Temperatur und der relativen Fuftfeuchtigkeit auf das Fraßvermögen von Syrphidenlarven (Diptera, Syrphidae). Ph.D. dissertation, University of Göttingen.

Wetzel, T. \& F. Schütte. 1988. Zur Schadens- und Bekämpfungsschwelle der Getreideblattlaus (Macrosiphum [Sitobion] avenae [Fabr.]) an Winterweizen. Nachrichtenbl. Dtsch. Pflanzenschutzdienst (Berl.) 40(12): 177-179.

Wissel, C. 1989. Theoretische Ökologie. Springer, Berlin.

Zadoks, J. C., H. C. Gao, F. H. Za \& G. D. Lin. 1974. A decimal code for growth stages of cereals. Weed Res. 14: 415-421.

Received for publication 8 July 1994; accepted 22 November 1994. 